\title{
Co-Processing of Biooils from Biomass Pyrolysis and Hydrocarbons Derived from Oil Sands
}

\author{
Maoqi Feng ${ }^{1}$ and Bin Yang ${ }^{2 *}$ \\ ${ }^{1}$ Chemical Engineering Department, Division of Chemistry and Chemical Engineering, Southwest Research Institute, USA \\ ${ }^{2}$ Department of Biological Systems Engineering, Washington State University, USA
}

Submission: March 17, 2017, Published: June 28, 2017

*Corresponding author: Bin Yang, Department of Biological Systems Engineering, Division of Chemistry and Chemical Engineering, Southwest Research Institute, USA, Tel: 509-372-7640; Email: bin.yang@wsu.edu

\begin{abstract}
Liquid biooils can be produced from thermo chemical processing of biomass by pyrolysis. Biooils cannot be used directly as transportation fuel because of their poor volatility, high viscosity, coking, corrosiveness, and cold flow problems. However, biooils can be upgraded into liquid transportation fuel by hydrodeoxygenation (HDO) with typical hydro treating procedure with conventional CoMo or NiMo catalysts in the current oil refinery facilities. Co-processing of biooils and hydrocarbons derived from oil sand provides an opportunity of processing the two feeds at the same time, which can be achieved by injection of pyrolytic biooils and vacuum gas oil (VGO) from bitumen into a fluid catalytic cracking (FCC) unit. The biooils are diluted into the VGO feed to be processed. For the blends of VGO and biooils, the biooils appeared to facilitate the cracking of the VGO and produce light ends, lower light cycle oil (LCO) and other heavier components, which makes the process economically attractive. This paper reviews the current status of co-processing of biooils and hydrocarbons, and proposes some possible solutions for co-processing of VGO with biooils and biopitches.
\end{abstract}

Keywords: hydrodesulphurization; straight-run gas oil; hydrodenitrogenation; deasphatling oil; vacuum gas oil; fluid catalytic cracking

\section{Introduction}

Bitumen from Alberta oil sands is heavy $\left(8^{\circ} \mathrm{C}-10^{\circ} \mathrm{C} \mathrm{API}\right)$ and viscous (2-5 million $\mathrm{CP}$ ) oil. In industry, bitumen is upgraded to syncrude with higher API gravity and lower viscosity for further refining. A typical method for syncrude upgrading is hydro processing the products from primary upgrading to make higher quality and saleable products.

Bio-oils derived from biomass have been attracting increasing attention as alternative sources of fuels and chemicals. Research on the fuel production from renewable sources by pyrolysis has received much recent interests. Renewable sources used in the pyrolysis of biomass are woody materials and marine algae; the latter are the main primary producer in oceans and they constitute the largest biomass in nature. Pyrolytic biooils are an alternative to fossil fuels. However, the high content of oxygenated compounds makes them thermal and chemically unstable. The oxygenated compounds can be removed by hydro processing, which is quite similar as fossil fuel upgrading. Several technical challenges remain for upgrading biooils to transport liquid fuel in a large scale. Therefore, this process is currently not economically attractive. Co-processing of biooils in conventional petroleum refining units can improve competiveness of refineries. It provides an alternative method for biooils upgrading and for the second generation biofuels production. Co-processing can reduce the costs of fuels and chemicals production from biofeeds by utilizing the existing production and distribution systems for petroleum-based products and avoiding the expensive capital investment.

The co-processing of guaiacol, an oxygenated molecule from biomass pyrolysis, with straight-run gas oil (SRGO) by hydrodesulphurization (HDS) process was reported [1]. During the co-processing, the HDS performance with CoMo/ Al203as catalyst decreased at low temperature and high contact time due to the formation of phenol intermediates. The phenol intermediates competed with sulfur containing molecules for adsorbing on hydrogenation/hydrogenolysis sites. At above $320^{\circ} \mathrm{C}$, complete HDO of guaiacol was observed and HDS proceeded without any further inhibition.

Recently, co-processing of biooils with fossil fuels by hydro treating was also reported [2]. Pyrolysis oils from 
lignocellulosic biomass were co processed by hydro treating with straight-run gas oil. In this process, both HDO and HDS reactions are essential. The influence of different oxygenated compounds from bioils on the hydro treatment of the straightrun gas oil was studied on a $\mathrm{CoMo} / \gamma-\mathrm{Al} 2 \mathrm{O} 3$ catalyst under industrial operating conditions. The oxygenated compounds included 2-propanol, cyclopentanone, anisole, guaiacol, propanoic acid, and ethyldecanoate. Reaction mechanisms of HDO reactions were proposed for each oxygenated compound, and their impact on the gas oil HDS, hydrodenitrogenation (HDN), and aromatic ring hydrogenation (HDCA) was determined.

The catalytic performances were not inhibited by 2-propanol, cyclopentanone, anisole, and guaiacol, while propanoic acid and ethyldecanoate had inhibition effects on HDS, HDN, and HDCA reactions. The inhibition is attributed to the competition between the HDS reactions and the methanation of $\mathrm{CO}$ and $\mathrm{CO} 2$ formed during the decomposition of ethers and acids. The impact on HDS conversion of dibenzothiophenic compounds was also studied, showing no differences of inhibition effects among these molecules.

Due to the presence of large amount of oxygenated compounds, biooils are more polar than fossil fuels and not easily mixed with hydrocarbons. In addition, the viscosity is quite different between biooils and bitumen. For co-processing of bitumen with biooils, pretreatment of bitumen is necessary. Co-processing of the pretreated bitumen and biooils might provide an alternative method for bitumen refining, and coprocessing of bitumen with biopitch will provide a better solution for biopitch application.

\section{Co-Processing of Biooils with Hydrocarbons Derived from Bitumen Upgrading}

Hydro treating is widely used for petroleum refining and biooils upgrading. Co-processing of a mixture of biooils and heavy vacuum oil (HVO, with $1.48 \mathrm{wt} \%$ sulfur content) was reported in literature at typical hydro treating conditions (300-450 ${ }^{\circ} \mathrm{C}$ ) with conventional hydro treating catalysts (sulfide NiMo/Al203) [3]. For biooils, the unsaturated $\mathrm{C}=\mathrm{C}$ bonds were hydrogenated first, then three different reactions occurred, including decarbonylation, decarbonylation, and hydrodeoxygenation. The straight chain alkanes obtained isomerizes and crack to lighter and isomerizes alkanes. When sunflower oil and HVO were hydro treated separately, 71\% yield of straight chain C15-C18 alkanes was produced based on carbon basis (the maximum theoretical yield is 95\%) for hydro treating of biooils under optimized reaction conditions. The rate of alkane production from pure sunflower oil was $100 \%$ at $350{ }^{\circ} \mathrm{C}$, which was greater than the HDSof HVO (41\% sulfur conversion). After sunflower oil was mixed with HVO, the yield of straight chain alkanes increased, indicating that the coprocessing of HVO with sunflower oil facilitated the reactions.
For a feedstock of a mixture of $5 \mathrm{wt} \%$ biooilsand $95 \mathrm{wt} \% \mathrm{HVO}$, the maximum theoretical straight chain $\mathrm{C} 15-\mathrm{C} 18$ yield from the sunflower oil increased to $87 \%$ from $75 \%$ yield with pure sunflower oil. The deactivation of catalysts for hydro treating of the biooils and VGO blend is often caused by deposits of coke and metals on the catalyst surface, eventually leading to plugging of the catalyst pores, thus severely limiting the lifetime of catalysts.

Hydro cracking is another method widely used both for biooil upgrading and petroleum refining. Co-processing of biooil with petroleum hydrocarbons was also reported in literature [4]. Glycerol and sorbitol are present in some biofuels and used as representative of biomass-derived oxygenates. Co-processing of glycerol and VGO by fluid catalytic cracking (FCC) process was conducted in an industrial FCC reactor with the conventional FCC catalysts. Results showed no significant change of the product selectivity. However, the final selectivity was higher than those calculated by considering a simple additive effect due to interactions between the hydrocarbon components and the glycerol reaction intermediates.

During co-processing, free radical intermediates from oxygenates in biooils may interact with bitumen, resulting product distribution changes (depends on conversion level). In the meantime, higher temperature required for heavy oil cracking might produce more carbon monoxide from oxygenates decomposition.

\section{Co-Processing of Biopitches with Heavy Oils from Bitumen}

Biopitch, which is used as a substitute for fossil pitches, is generally produced as a byproduct from biomass pyrolysis and biooil distillation. The oxygen content in biopitch is about 20 $\mathrm{wt} \%$, while in mineral pitches it is below $2 \mathrm{wt} \%$. Eucalyptus tar pitches, which are produced in large scale as a byproduct in charcoal manufacturing industry in Brazil, contain some macro molecules, mainly phenolic, guaiacyl, and siringyl units commonly derived from lignin. The low aromaticity (60-70\%), high $0 / C$ atomic ratios (0.20-0.27\%), and large molar mass distribution distinguish biopitches from fossil pitches [5]. The viscosity of bitumen and biopitch is quite similar. Table 1 compares the properties of Athabasca bitumen and biopitch [6].

Although it was not reported in literature, co-processing of bitumen and biopitches provides another pathway for biopitches application. Biopitch is at first blended with bitumen at suitable temperature, then solvent deasphatling of the mixture to remove asphaltenes and heavy components from the mixture. The deasphatling oil (DAO) and the heavy oil produced from delayed coking of asphaltenes will then blend with biooils for upgrading by hydro treating to produce transportation fuels. A block diagram of the integrated refinery is shown in (Figure 1). 


\section{Recent Advances in Petrochemical Science}

Table 1: A comparison of Athabasca bitumen [6] with biopitch [5].

\begin{tabular}{|c|c|c|}
\hline Property & Athabasca Bsitumen & Biopitch \\
\hline Components & $\begin{array}{c}48.5 \% \\
\text { aromatics,16.8\% } \\
\text { resins, } 18.6 \% \\
\text { asphaltenes, } 16.1 \% \\
\text { saturates }\end{array}$ & $\begin{array}{c}50 \% \text { aromatic and } \\
\text { olefinic carbons, }>30 \% \\
\text { carbon linked to oxygen }\end{array}$ \\
\hline $\mathrm{C}, \%$ & 83.2 & 69.6 \\
\hline $\mathrm{H}, \%$ & 9.7 & 6.4 \\
\hline $0, \%$ & 1.7 & 23.6 \\
\hline $\mathrm{N}, \%$ & 0.4 & 0.4 \\
\hline S, $\%$ & 5.3 & -- \\
\hline $\mathrm{Ni}, \mathrm{ppm}$ & 93 & -- \\
\hline $\mathrm{V}, \mathrm{ppm}$ & 259 & -- \\
\hline Density, kg/L & $1.006-1.016$ & 1.163 \\
\hline Viscosity (Pa s) & $3.63-4.35\left(\right.$ at $\left.60{ }^{\circ} \mathrm{C}\right)$ & 5.45 (at $120^{\circ} \mathrm{C}$ ) \\
\hline
\end{tabular}

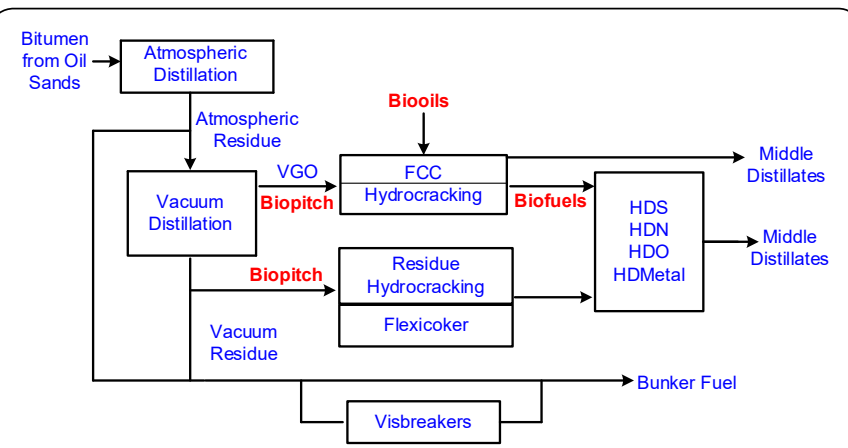

Figure 1: A process block diagram of the integrated refinery proposed in this paper.

\section{Conclusion}

In summary, the co-processing of biooils with fossil fuels provides an economical and synergistic pathway for liquid fuels production using the current existing refinery facilities that enables biofuels to the fuel market immediately. However, the compatibility of the co-processing with current refinery, techno-economic analysis, and life cycle assessment of the coprocessing that are vital to its success need further evaluation.

\section{References}

1. Bui VN, Toussaint G, Laurenti D, Mirodatos C, Geantet C, et al. (2009) Co-processing of pyrolisis bio oils and gas oil for new generation of biofuels: Hydrodeoxygenation of guaiacol and SRGO mixed feed. Catalysis Today 143(1-2): 172-178.

2. Pinheiro A, Hudebine D, Dupassieux N, Geantet C (2009) Impact of oxygenated compounds from lignocellulosic biomass pyrolysis oils on gas oil hydro treatment. Energy \& Fuels 23(2): 1007-1014.

3. Huber GW, Connor PO, Corma A (2007) Processing biomass in conventional oil refineries: Production of high quality diesel by hydro treating vegetable oils in heavy vacuum oil mixtures. Applied Catalysis A: General 329: 120-129.

4. Corma A, Huber GW, Sauvanaud L, Connor PO (2007) Processing biomass-derived oxygenates in the oil refinery: Catalytic cracking (FCC) reaction pathways and role of catalyst, Journal of Catalysis 247(2): 307-327.

5. Prauchner MJ, Pasa VMD, Otani S, Otani C (2005) Biopitch-based general purpose carbon fibers: Processing and properties. Carbon 43(3): 591-597.

6. Zhao B, Zhang X, Shaw JM (2008) Interplay between the physical properties of Athabasca bitumen + diluents mixtures and coke deposition on a commercial hydro processing Catalyst. Energy \& Fuels 22(3): 1747-1758.

\section{Your next submission with Juniper Publishers will reach you the below assets}

- Quality Editorial service

- Swift Peer Review

- Reprints availability

- E-prints Service

- Manuscript Podcast for convenient understanding

- Global attainment for your research

- Manuscript accessibility in different formats

( Pdf, E-pub, Full Text, Audio)

- Unceasing customer service

Track the below URL for one-step submission https://juniperpublishers.com/online-submission.php 